\title{
PERAN KEADILAN ORGANISASI, KARAKTERISTIK PEKERJAAN DAN PEMBERDAYAAN PSIKOLOGIS TERHADAP KEINGINAN UNTUK MENETAP (INTENTION TO STAY)
}

\author{
Vany Widya Pricillia ${ }^{1}$ dan Rostiana ${ }^{2}$ \\ ${ }^{1}$ Fakultas Psikologi, Universitas Tarumanagara Jakarta \\ Email : vany.pricillia@gmail.com \\ ${ }^{2}$ Fakultas Psikologi, Universitas Tarumanagara Jakarta \\ Email : rostiana@fpsi.untar.ac.id
}

\begin{abstract}
ABSTRAK
Keinginan untuk menetap (intention to stay) adalah kesediaan karyawan untuk tetap bersama dengan perusahaan atau organisasi. Banyak faktor yang dapat mempengaruhi keinginan untuk menetap karyawan di perusahaan. Faktor tersebut dapat berasal dari internal maupun eksternal. Penelitian ini dilakukan untuk menguji peran dari keadilan organisasi, karakteristik pekerjaan dan pemberdayaan psikologis terhadap keinginan untuk menetap karyawan. Hasil dari penelitian ini nantinya dapat digunakan oleh perusahaan untuk melakukan perubahan demi mempertahankan karyawan yang berkualitas. Penelitian ini dilakukan secara kuantitatif dengan menyebarkan kuesioner secara online terhadap 187 karyawan milenial di PT. XY. Kuesioner yang digunakan terdiri dari empat aspek yang diukur yakni keadilan organisasi, karakteristik pekerjaan, pemberdayaan psikologis dan keinginan untuk menetap. Data yang diperoleh dianalisa menggunakan uji regresi linier dan regresi berganda. Hasil uji regresi menunjukkan bahwa keadilan organisasi, karakteristik pekerjaan dan pemberdayaan organisasi memiliki peran yang signifikan terhadap keinginan untuk menetap karyawan milenial. Dalam uji regresi berganda diperoleh hasil bahwa variabel yang paling memiliki peran terhadap keinginan untuk menetap karyawan milenial adalah karakteristik pekerjaan
\end{abstract}

Kata kunci : keadilan organisasi, karakteristik pekerjaan, pemberdayaan psikologis, keinginan untuk menetap (intention to stay), milenial

\section{PENDAhUluan}

Era globalisasi ekonomi membuat persaingan antar industri semakin ketat. Industri dituntut mengembangkan strategi yang efektif untuk meningkatkan keunggulan yang dimilikinya. Demi mendukung hal tersebut maka dibutuhkan sumber daya manusia yang berkualitas. Akan tetapi, tren yang ada saat ini karyawan yang berkualitas cenderung tidak bertahan lama bekerja di organisasi. Hal tersebut pastinya merugikan perusahaan terlebih saat jika karyawan yang berkualitas berasal dari generasi $\mathrm{Y}$ atau milenial.

Milenial merupakan generasi yang memiliki pemikiran yang bebas, kreatif dan peka terhadap teknologi. Hal tersebut membantu mereka untuk lebih cepat beradaptasi terhadap perubahan dibandingkan generasi sebelumnya. Akan tetapi, dengan daya adaptasi yang cepat, pemikiran yang bebas dan peka terhadap teknologi justru membuat karyawan milenial cenderung tidak bertahan lama di suatu pekerjaan (Pramita, 2017). Data menyebutkan bahwa sebesar $71 \%$ karyawan milenial tidak mau terikat secara aktif pada pekerjaan (Gallup's report How Millennials Wants to Work and Live, 2016). Data lainnya mengungkapkan bahwa hanya sekitar $27 \%$ milenial yang memiliki keinginan untuk bertahan di organisasi. (Survey Deloitte tentang Milenial di 29 negara tahun 2016) 
Tidak hanya di negara maju, negara berkembang seperti Indonesia juga mengalami hal tersebut. Survey dari situs referensi karir Jobplanet dari tahun 2015 hingga 2017 menyatakan bahwa Gen Y memiliki

tingkat kesetiaan yang lebih rendah dibandingkan generasi sebelumnya. Hanya sebesar 9,5\% karyawan milenial yang dapat bertahan di tempat kerja selama lima tahun atau lebih sedangkan 76,7\% karyawan milenial hanya bertahan bekerja di perusahaan dengan masa kerja selama 1-2 tahun. Setelah 2 tahun, mereka akan mencari pekerjaan baru.

Salah satu perusahaan yang mengalami rendahnya karyawan milenial yang menetap di tempat kerja adalah PT. XY. Perusahaan PT. XY bergerak di bidang perdagangan alat-alat kesehatan dan farmasi dari luar negeri. Data yang diperoleh dari bagian SDM mengungkapkan bahwa $60 \%$ karyawan milenial dari total keseluruhan karyawan hanya menetap di organisasi dengan rentang waktu kerja antara 1 - 2 tahun. Setelahnya, karyawan milenial tersebut mulai berpindah tempat kerja.

Keinginan karyawan menetap di pekerjaan (intention to stay) adalah kesediaan karyawan untuk tetap bekerja di organisasi. Keinginan untuk menetap merupakan cerminan level komitmen karyawan terhadap organisasi (Larkin, Dias \& Vega, 2016). Selama ini, penelitian yang terkait dengan keinginan untuk menetap karyawan dan faktor-faktor yang mempengaruhi keinginan menetap tersebut belum banyak dilakukan. Penelitian terdahulu lebih berfokus mengungkapkan alasan dari keinginan karyawan untuk berpindah kerja. (Sidharta dan Margaretha, 2011; Shobirin, Minarsih \& Fathoni, 2016)

Pada dasarnya, dorongan karyawan untuk tetap bekerja di organisasi adalah memenuhi kebutuhan. Berdasarkan teori McClelland, ada tiga kebutuhan manusia yaitu kebutuhan berprestasi, berafiliasi dan memegang kendali untuk membuat keputusan sesuai dengan keinginan diri sendiri. Karyawan akan merasa kebutuhannya terpenuhi di tempat kerja apabila ia merasa diperlakukan sama atau adil oleh perusahaan. Pengalaman karyawan diperlakukan sama atau adil di perusahan disebut dengan keadilan organisasi.

Keadilan organisasi dikelompokkan ke dalam 3 kategori yaitu keadilan distributif, keadilan prosedural dan keadilan interaksi. Keadilan distributif diartikan sebagai adanya keseimbangan antara kontribusi yang diberikan karyawan dengan imbalan yang mereka terima dari perusahaan. Singkatnya, organisasi dikatakan adil oleh karyawan apabila memberikan gaji dan reward yang sesuai dengan hasil kerja mereka. Sedangkan keadilan prosedural merupakan persepsi karyawan tentang keadilan dari proses dan prosedur yang digunakan oleh organisasi atau perusahaan dalam membuat keputusan termasuk keputusan terhadap reward yang diberikan kepada mereka. Organisasi dapat dikatakan adil oleh karyawan apabila dalam pengambilan keputusan, karyawan diberikan kesempatan untuk memberikan pendapat dan pandangannya. Terakhir, keadilan interaksi merujuk kepada persepsi karyawan terhadap perlakuan adil yang mereka dapatkan dari figur otoritas. Organisasi dipandang adil terhadap karyawan apabila hubungan antara atasan dan bawahan terjalin baik seperti mendapatkan perlakuan yang baik dan sewajarnya, memperoleh informasi yang akurat dan jujur dari atasan, dll. Apabila karyawan memiliki persepsi keadilan organisasi yang tinggi, maka karyawan akan merasa puas dan muncul komitmen pada diri karyawan sehingga terdorong secara sukarela untuk bekerja di perusahaan dalam waktu yang lama. (Dewettinck \& Ameijde, 2011)

Studi yang membahas peran keadilan organisasi terhadap keinginan untuk menetap karyawan sampai saat ini belum menemukan kesimpulan yang final terutama ditinjau berdasarkan tiga kategori atau dimensi. Hasil penelitian Nojani, Arjmandnia, Afrooz \& Rajabi (2012) menyatakan bahwa hanya 
keadilan distributif dan keadilan prosedural yang secara signifikan dapat mempengaruhi kepuasan kerja karyawan serta mempengaruhi keinginan berpindah karyawan. Sedangkan keadilan interaksi tidak memiliki pengaruh sama sekali. Penelitian lain dilakukan oleh Bayarcelik dan Findliki (2016) menunjukkan bahwa keadilan distributif yang mempengaruhi kepuasan karyawan sehingga ingin tetap bekerja di organisasi. Brandis et al. (2016) mendapatkan hasil penelitian bahwa ketiga dimensi dari keadilan organisasi berpengaruh secara signifikan terhadap kepuasan karyawan yang bekerja di pelayanan kesehatan. Terakhir, George \& Wallio (2017) menunjukkan keadilan prosedural yang mempengaruhi karyawan menetap di organisasi. Oleh karenanya, penelitian kali ini ingin menguji kembali hubungan antara keadilan organisasi dengan keinginan untuk menetap.

Selain perlakuan yang adil, kebutuhan karyawan juga akan dapat terpenuhi melalui tugas dan pekerjaan yang dilakukan dalam organisasi. Melalui pekerjaan karyawan dapat termotivasi bekerja hal ini dikarenakan adanya kriteria-kriteria tertentu. Kriteria tersebut yang dikenal dengan karakteristik pekerjaan. Karakteristik pekerjaan diartikan sebagai objektif dari pekerjaan terutama sejauh mana pekerjaan dirancang sehingga dapat meningkatkan motivasi kerja internal dan kepuasan kerja karyawan (Hackman \& Oldham dalam Hadi \& Adil, 2010). Karakteristik pekerjaan terdiri dari lima dimensi utama yaitu skill variety, task identity, task significant, autonomy dan feedback.

Hasil penelitian sebelumnya mengenai karakteristik pekerjaan mengungkapkan bahwa karakteristik pekerjaan memiliki pengaruh terhadap komitmen karyawan terhadap organisasi (Ozturk, Hancer \& Im, 2014; Djastuti, 2011). Secara logika, ketika karyawan sudah berkomitmen terhadap organisasi, maka karyawan tersebut pastinya bersedia mengeluarkan usaha yang lebih guna membantu keberlangsungan organisasi termasuk bersedia untuk terus bekerja di dalam organisasi. Akan tetapi, belum ditemukan studi yang menguji langsung antara karakteristik pekerjaan dengan keinginan untuk menetap karyawan di organisasi yang menjadi alasan penelitian ini dibuat.

Terakhir, atasan memiliki peran penting terhadap pemenuhan kebutuhan karyawan di perusahaan. Salah satu caranya adalah melakukan pemberdayaan. Pemberdayaan diartikan sebagai pemberian kesempatan kepada karyawan untuk menggunakan keahlian yang dimiliki dalam membuat keputusan terkait dengan pekerjaan. Ketika memiliki persepsi bahwa dirinya memberikan pengaruh terhadap pekerjaan atau perusahaan maka karyawan dapat dikatakan sudah mengalami pemberdayaan psikologis.

Thomas \& Velthouse (dalam Spreitzer, 1995) mendefinisikan pemberdayaan psikologis sebagai peningkatan motivasi intrinsik terhadap tugas yang terwujud dalam seperangkat empat kognisi yang mencerminkan orientasi individu terhadap peran kerjanya yakni meaning, competence, self determintation, dan impact. Meaning berarti karyawan merasa pekerjaannya sangat berarti bagi dirinya sehingga mereka akan melakukan pekerjaannya secara maksimal. Competence berarti karyawan mempercayai bahwa dirinya memiliki keterampilan yang cukup untuk melakukan pekerjaan yang diberikan oleh perusahaan. Self determination artinya karyawan merasa bebas untuk membuat keputusan dan bertindak dalam berbagai situasi di pekerjaan. Sedangkan impact merupakan perasaan karyawan bahwa ia mampu memberikan pengaruh yang penting terhadap perusahaan.

Beberapa studi yang dilakukan sebelumnya terkait dengan pemberdayaan psikologis mendapatkan hasil bahwa pemberdayaan psikologis dapat meningkatkan komitmen karyawan terhadap organisasi (Najafi, Noruzy, Shirkouhi \& Dalvand, 2011; Ouyang, Zhou \& Qu, 2015). Namun, studi yang membahas hubungan pemberdayaan psikologis secara langsung mempengaruhi keinginan untuk menetap di 
organisasi masih minim dilakukan. Hal ini yang mendorong peneliti untuk melihat apakah ada peran pemberdayaan psikologis terhadap keinginan untuk mentap karyawan.

Berdasarkan latar belakang tersebut, tujuan dari penelitian ini adalah menguji peran keadilan organisasi, karakteristik pekerjaan dan pemberdayaan psikologis terhadap keinginan untuk menetap karyawan. Masalah dalam penelitian ini dirumuskan menjadi beberapa pertanyaan yakni : a)eberapa tinggi tingkat keinginan untuk menetap pada karyawan milenial di PT. XY b)apakah keadilan organisasi berperan terhadap keinginan untuk menetap karyawan c) apakah karakteristik pekerjaan memainkan peranan terhadap keinginan untuk menetap karyawan d) apakah pemberdayaan psikologis berperan terhadap keinginan untuk menetap karyawan.e) apakah keadilan organisasi, karakteristik kerja atau pemberdayaan psikologis yang memainkan peran paling besar terhadap keinginan untuk menetap pada karyawan milenial di PT. XY.

Berikut ini adalah gambaran model penelitian kali ini :

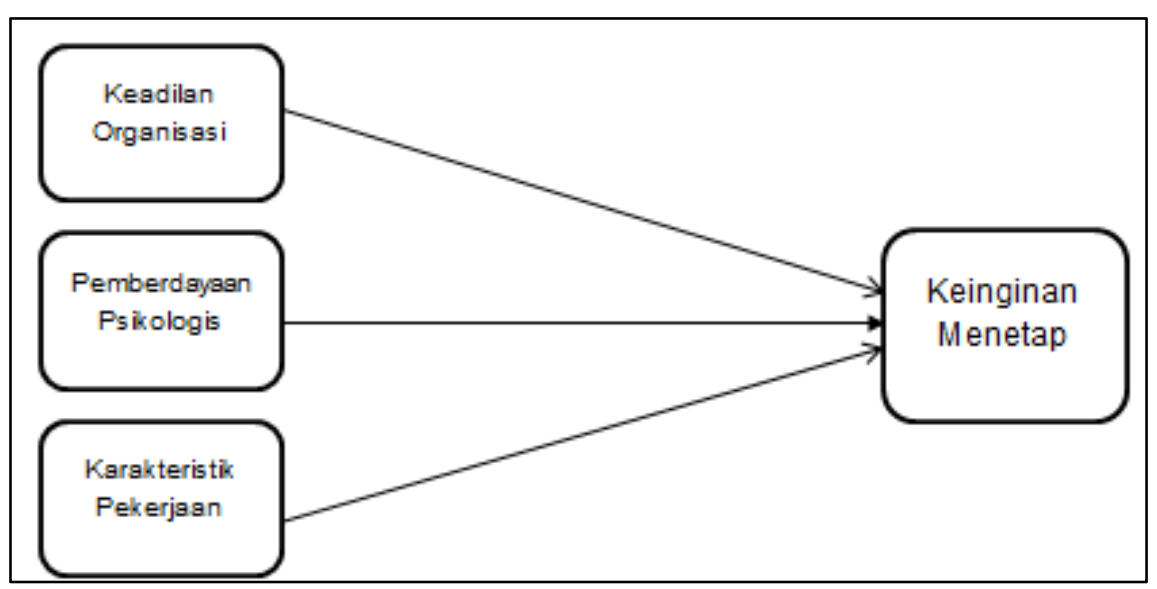

Gambar 1. Model Penelitian

\section{METODE PENELITIAN}

Partisipan diambil dari populasi adalah karyawan milenial yang bekerja di PT.XY. Peneliti mengambil partisipan sebanyak 187 orang. Berdasarkan jenis kelamin, jumlah partisipan laki-laki sebanyak 107 orang atau sebesar 57,2\%. Sedangkan jumlah partisipan perempuan sebanyak 80 orang atau sebesar 42,8\%. Penelitian menggunakan metode kuantitatif dan non experimental. Menggunakan 4 variabel yaitu keadilan organisasi, karakteristik pekerjaan, pemberdayaan psikologis dan keinginan untuk menetap. Peneliti menyebarkan kuesioner yang diisi oleh partisipan. Teknik sampling yang digunakan adalah purposive sampling karena hanya menyasar kepada karyawan dari generasi Y (milenial) di PT.XY. Teknik analisis dilakukan dengan menggunakan uji regresi. Pertama diawali dengan uji regresi linier antara variabel keadilan organisasi, karakteristik pekerjaan dan pemberdayaan psikologis terhadap keinginan untuk menetap. Setelah itu dilakukan uji regresi berganda antara ketiga variabel bebas dengan keinginan untuk menetap.

Keadilan organisasi diukur dengan menggunakan alat ukur keadilan organisasi dari Moorman (1991) yang telah diadaptasi oleh Johnson (2007). Pada penelitian kali ini, peneliti menggunakan alat ukur keadilan organisasi dari Johnson tersebut namun yang sudah diadaptasi dengan menggunakan bahasa Indonesia dari penelitian Maya Ferviana (2009). Alat ukur tersebut terdiri dari 3 dimensi yakni keadilan distributif, keadilan prosedural, keadilan interaksi dengan total 18 butir pernyataan. Respon jawaban 5 skala Likert ( $1=$ sangat tidak adil, 5=sangat adil). Contoh butir penyataannya adalah perlakuan 
perusahaan kepada saya sehubungan dengan tanggung jawab yang diberikan kepada saya (keadilan distributif), kesempatan saya untuk memberikan informasi yang akurat dalam proses pengambilan keputusan di perusahaan (keadilan prosedural), relasi kerja saya dengan atasan (keadilan interaksi). Uji validitas dan reliabilitas yang dilakukan terhadap 187 responden didapatkan nilai koefisien cronbach's alpha yang baik yakni $\alpha=0.92$.

Karakteristik pekerjaan diukur menggunakan alat ukur yang dikembangkan oleh Colquitt, LePine \& Wesson pada tahun 2009. Namun untuk penelitian kali ini, peneliti menggunakan alat ukur yang sudah diadaptasi dengan menggunakan bahasa Indonesia dari penelitian Lunardi (2012). Alat ukur ini terdiri 5 dimensi yakni otonomi, umpan balik kerja, signifikansi kerja, identitas tugas dan variasi keterampilan. Total butir pernyataan sebanyak 30 butir. Respon untuk menjawab pernyataan menggunakan 5 skala Likert ( 1 = sangat tidak setuju, 5 = sangat setuju). Contoh butir pernyataannya antara lain pekerjaan saya biasanya melibatkan karya lengkap yang memiliki awal dan akhir yang jelas, saya bebas menentukan cara yang ingin saya gunakan dalam menyelesaikan tugas saya sehari-hari. Secara keseluruhan alat ukur ini memiliki internal konsistensi secara keseluruhan mencapai 0.77 , untuk masing-masing dimensi memiliki internal konsistensi cronbach's alpha mulai dari 0.61 sampai dengan 0.80. Namun dari hasil pengolahan data terdapat 7 butir yang tidak reliabel memiliki nilai corrected item-total correlation berada di bawah nilai 0.2 atau bertanda negatif sehingga item tersebut dibuang.

Pemberdayaan psikologis diukur dengan menggunakan alat ukur Psychological Empowerment Scale (PEC) dari Thomas dan Volthouse (1990) yang diadopsi oleh Spreitzer pada tahun 1995. Peneliti menggunakan alat ukur PEC yang sudah diadaptasi dengan menggunakan bahasa Indonesia dari penelitian Putri (2017). Terdiri dari 15 butir pernyataan terdiri 4 dimensi yakni meaning, competence, self determination dan impact. Skala yang digunakan adalah 5 skala Likert $(1=$ sangat tidak setuju, $5=$ sangat setuju). Contoh - contoh butir pernyataannya di antaranya adalah pekerjaan yang saya lakukan sangat penting bagi saya, saya yakin pada kemampuan saya untuk melakukan aktivitas pekerjaan saya, saya memiliki otonomi dalam menentukan bagaimana saya melakukan pekerjaan saya, dan saya memiliki konribusi yang besar dalam memajukan perusahaan. Nilai reliabiltasnya cukup baik $(\alpha=0.88)$. Keinginan untuk menetap (intention to stay) diukur dengan menggunakan alat ukur yang dikembangkan oleh Stassen dan Ursel (2009). Terdiri dari 3 butir pernyataan asli dan 3 butir pernyataan tambahan. Peneliti melakukan uji validitas dan reliabilitas menggunakan 187 responden, hasilnya nilai koefisien cronbach's alpha $(\alpha=0.91)$. Skala alat ukur ini menggunakan 5 skala Likert $(1=$ sangat tidak setuju , 5 = sangat setuju). Salah satu contoh butir pernyataannya adalah saya berharap bisa terus bekerja selama mungkin di perusahan ini.

\section{HASIL DAN PEMBAHASAN}

Tujuan dari penelitian ini adalah menguji peran keadilan organisasi, karakteristik pekerjaan dan pemberdayaan psikologis terhadap keinginan untuk menetap karyawan. Terdapat lima rumusan permasalahan yang perlu dijawab agar tujuan penelitian ini tercapai. Berdasarkan pengolahan data di lapangan, diperoleh hasil bahwa karyawan milenial di PT. XY rata-rata ingin terus menetap di perusahaan. Hal ini ditunjukkan dari nilai rata-rata empirik/mean (Tabel 1) lebih besar dari nilai titik tengah alat ukur keinginan untuk menetap sebesar 3.00. 
Tabel 1

Gambaran Data Keinginan Untuk Menetap (Intention to Stay)

\begin{tabular}{lcccccc}
\hline & & $\mathrm{N}$ & Min. & Max. & Mean & SD \\
\hline $\begin{array}{l}\text { Keinginan untuk } \\
\text { (Intention to Stay) }\end{array}$ & Menetap & 187 & 1.00 & 5.00 & 3.72 & 0.68 \\
\hline
\end{tabular}

Berdasarkan pengolahan data diperoleh hasil bahwa keadilan organisasi, karakteristik pekerjaan dan pemberdayaan psikologis memiliki korelasi terhadap keinginan untuk menetap dari karyawan. Nilai korelasi antara keadilan organisasi dengan keinginan untuk menetap adalah $0.42^{* *}$, nilai korelasi antara variabel karakteristik pekerjaan dengan keinginan untuk menetap sebesar $0.49 * *$ dan nilai korelasi antara variabel pemberdayaan psikologis dan keinginan untuk menetap adalah sebesar $0.35^{* *}$ (lihat Tabel 2). Hal ini dapat disimpulkan bahwa keinginan untuk menetap karyawan dipengaruhi oleh ketiga variabel tersebut secara parsial dan hasil ini pun menjawab rumusan permasalahan penelitian ini.

Selain itu, peneliti juga melakukan uji regresi berganda. Hal ini dilakukan untuk menguji faktor atau variabel yang memainkan peran paling besar terhadap keinginan untuk menetap karyawan khususnya karyawan milenial di PT. XY. Hasil yang diperoleh adalah karakteristik pekerjaan menjadi faktor yang memainkan peran paling besar terhadap keinginan untuk menetap karyawan dengan nilai koefisien $\beta=$ 0.60 (lihat Gambar 2). Kemudian faktor lainnya yang memainkan peran terhadap keinginan untuk menetap karyawan adalah keadilan organisasi dengan nilai koefisien $\beta=0.44$. Sedangkan pemberdayaan psikologis tidak memiliki pengaruh yang signifikan terhadap keinginan untuk menetap karyawan dengan nilai koefisien $\beta=0.21, p>0.05$

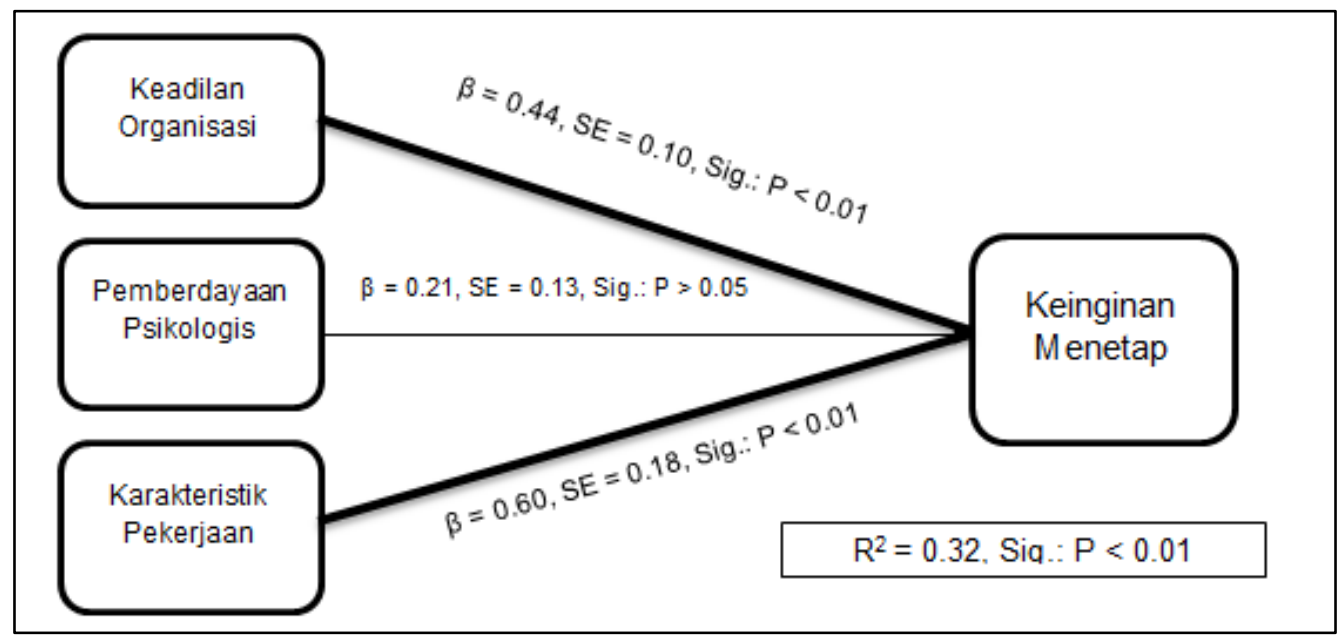

Gambar 2. Hasil Uji Regresi Berganda Keadilan Organisasi, Pemberdayaan Psikologis, Karakteristik Pekerjaan terhadap Keinginan untuk Menetap 
Tabel 2

\section{Gambaran Korelasi Antar Variabel dan Dimensi Penelitian}

\begin{tabular}{|c|c|c|c|c|c|c|c|c|c|c|c|c|c|c|c|c|}
\hline & 1 & 2 & 3 & 4 & 5 & 6 & 7 & 8 & 9 & 10 & 11 & 12 & 13 & 14 & 15 & 16 \\
\hline $\begin{array}{ll}\text { 1. } & \text { Keadilan } \\
& \text { Organisasi }\end{array}$ & - & $0.81 * *$ & $0.86^{* *}$ & $0.80 * *$ & $0.28 * *$ & $0.15^{*}$ & $0.17^{*}$ & $0.23 * *$ & $0.26^{* *}$ & $0.51 * *$ & $0.36^{* *}$ & $0.57 * *$ & $0.30 * *$ & 0.13 & -0.06 & $0.47 * *$ \\
\hline $\begin{array}{l}\text { 2. Keadilan } \\
\text { Distributif }\end{array}$ & $0.81 * *$ & - & $0.67 * *$ & $0.45 * *$ & 0.12 & 0.02 & 0.10 & 0.03 & $0.15^{*}$ & $0.35^{* *}$ & $0.27 *$ & $0.43 * *$ & $0.22 * *$ & 0.33 & -0.02 & $0.38^{* *}$ \\
\hline $\begin{array}{ll}\text { 3. } & \text { Keadilan } \\
& \text { Prosedural }\end{array}$ & $0.86^{* *}$ & $0.67 * *$ & - & $0.57 * *$ & $0.28 * *$ & $0.15^{*}$ & 0.14 & $0.27 * *$ & $0.26^{* *}$ & $0.45^{* *}$ & $0.35 * *$ & $0.44 * *$ & $0.29 * *$ & 0.10 & -0.03 & $0.42 * *$ \\
\hline 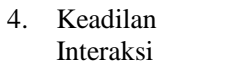 & $0.80 * *$ & $0.45 * *$ & $0.57 * *$ & - & $0.26 * *$ & $0.17 *$ & $0.15^{*}$ & $0.28 * *$ & $0.21 * *$ & $0.47 * *$ & $0.35 * *$ & $0.56 * *$ & $0.23 * *$ & $0.15^{*}$ & -0.09 & $0.37 * *$ \\
\hline $\begin{array}{l}\text { 5. Pemberdayaan } \\
\text { Psikologis }\end{array}$ & $0.28 * *$ & 0.12 & $0.28 * *$ & $0.26 * *$ & - & $0.76 * *$ & $0.75 * *$ & $0.78 * *$ & $0.82 * *$ & $0.56^{* *} *$ & $0.36 * *$ & $0.27 * *$ & $0.48 * *$ & $0.54 * *$ & -0.13 & $0.35^{* *}$ \\
\hline 6. Meaning & $0.15^{*}$ & 0.18 & $0.15^{*}$ & $0.17 *$ & $0.76^{* *}$ & - & $0.51 * *$ & $0.46 * *$ & $0.49 * *$ & $0.45^{* *}$ & $0.26 * *$ & $0.21 * *$ & $0.47 * *$ & $0.41 * *$ & -0.13 & $0.36^{* *}$ \\
\hline 7. Competence & $0.17 *$ & 0.10 & 0.14 & $0.15^{*}$ & $0.75 * *$ & $0.50 * *$ & - & $0.50 * *$ & $0.51 * *$ & $0.44 * *$ & $0.24 * *$ & $0.20 * *$ & $0.35 * *$ & $0.60 * *$ & $-0,10$ & $0.21 * *$ \\
\hline $\begin{array}{l}\text { 8. Self } \\
\text { Determination }\end{array}$ & $0.23 * *$ & 0.32 & $0.27 * *$ & $0.28 * *$ & $0.78 * *$ & $0.46 * *$ & $0.50 * *$ & - & $0.55^{* *}$ & $0.36^{* *}$ & $0.32 * *$ & 0.13 & $0.23 * *$ & $0.32 * *$ & -0.03 & $0.19 * *$ \\
\hline 9. Impact & $0.26 * *$ & $0.15^{*}$ & $0.26^{* *}$ & $0.21 * *$ & $0.82 * *$ & $0.49 * *$ & $0.51 * *$ & $0.55^{* *}$ & - & $0.49 * *$ & $0.33 * *$ & $0.31 * *$ & $0.46 * *$ & $0.41 * *$ & -0.17 & $0.31 * *$ \\
\hline $\begin{array}{l}\text { 10. Karakterisik } \\
\text { Pekerjaan }\end{array}$ & $0.51 * *$ & $0.35^{* *}$ & $0.44 * *$ & $0.47 * *$ & $0.56 * *$ & $0.44 * *$ & $0.44 * *$ & $0.36^{* *}$ & $0.49 * *$ & - & $0.59 * *$ & $0.71 * *$ & $0.72 * *$ & $0.64 * *$ & 0.10 & $0.49 * *$ \\
\hline 11. Autonomy & $0.36 * *$ & $0.26 * *$ & $0.34 * *$ & $0.35 * *$ & $0.36 * *$ & $0.26 * *$ & $0.24 * *$ & $0.31 * *$ & $0.32 * *$ & $0.59 * *$ & - & $0.33 * *$ & $0.23 * *$ & $0.24 * *$ & $0.25^{* *}$ & $0.20 * *$ \\
\hline 12. Job feedback & $0.57 * *$ & $0.42 * *$ & $0.44 * *$ & $0.56 * *$ & $0.27 * *$ & $0.21 * *$ & $0.20 * *$ & 0.13 & $0.31 * *$ & $0.71 * *$ & $0.33 * *$ & - & $0.34 * *$ & $0.23 * *$ & -0.80 & $0.40 * *$ \\
\hline 13. Task Significant & $0.30 * *$ & $0.21 * *$ & $0.29 * *$ & $0.22 * *$ & $0.48 * *$ & $0.46 * *$ & $0.35 * *$ & $0.22 * *$ & $0.46 * *$ & $0.72 * *$ & $0.23 * *$ & $0.34 * *$ & - & $0.55 * *$ & -0.03 & $0.53^{* *}$ \\
\hline 14. Task Identity & 0.13 & 0.33 & 0.10 & $0.14^{*}$ & $0.54 * *$ & $0.41 * *$ & $0.63 * *$ & $0.32 * *$ & $0.41 * *$ & $0.64 * *$ & $0.24 * *$ & $0.23 * *$ & $0.55 * *$ & - & -0.08 & $0.24 * *$ \\
\hline 15. Skill Variety & -0.06 & -0.27 & -0.03 & -0.91 & $-0,13$ & $-0,13$ & -0.10 & -0.03 & $-0.17 *$ & 0.10 & $0.25^{* *}$ & -0.08 & -0.03 & -0.08 & - & -0.03 \\
\hline $\begin{array}{l}\text { 16. Keinginan } \\
\text { untuk Menetap }\end{array}$ & $0.48 * *$ & $0.38^{* *}$ & $0.4^{* *}$ & $0.37 * *$ & $0.36 * *$ & $0.35^{* *}$ & $0.21 * *$ & $0.19 * *$ & $0.31 * *$ & $0.49 * *$ & $0.20 * *$ & $0.40 * *$ & $0.53 * *$ & $0.24 * *$ & -0.03 & - \\
\hline
\end{tabular}


Oleh karena itu, hasil penelitian kali ini sejalan dengan hasil penelitian Ali (2015) yang menyatakan bahwa karakteristik pekerjaan memiliki relasi yang signifikan dan negatif terhadap keinginan untuk berpindah kerja karyawan. Artinya keinginan berpindah kerja karyawan tinggi apabila karakteristik pekerjaan dirasa tidak memenuhi kebutuhan atau keinginan karyawan. Sebaliknya, jika pekerjaan memiliki karakteristik yang dapat memenuhi kebutuhan karyawan maka keinginan untuk pindah kerja karyawan rendah dan karyawan cenderung ingin menetap di perusahaan.

Jika ditinjau dari dimensi karakteristik pekerjaan, yang paling berperan signifikan terhadap keinginan untuk menetap adalah dimensi task significant dan job feedback. (lihat nilai korelasi pada tabel 2). Hal ini dapat diartikan bahwa jika karyawan merasa pekerjaannya yang dilakukan memberikan pengaruh terhadap organisasi maupun orang lain dan dirinya berkembang karena adanya umpan balik dari organisasi (atasan) terhadap pekerjaan maka secara tidak langsung kebutuhannya yakni berprestasi dan berafiliasi akan terpenuhi. Apabila kebutuhannya sudah terpenuhi, timbul komitmen dalam diri karyawan terhadap perusahaan maka akan sukarela karyawan mempertahankan diri untuk terus bekerja di organisasi tersebut.

Hasil penelitian ini sejalan dengan penelitian Djastuti (2011) yang menyatakan bahwa adanya pengaruh positif dan signifikan antara karakteristik pekerjaan terhadap komitmen karyawan. Selain itu, hasil penelitian Ozturk et al. (2014) juga menyatakan bahwa karakteristik pekerjaan khususnya task significant dan job feedback memiliki peran yang signifikan terhadap komitmen organisasi. Ketika karyawan sudah memiliki komitmen yang tinggi terhadap organisasi maka karyawan akan sukarela untuk menetap di perusahaan.

\section{KESIMPULAN DAN SARAN}

Mengacu pada hasil penelitian, dapat disimpulkan bahwa keadilan organisasi, karakteristik pekerjaan dan pemberdayaan psikologis memiliki peran yang signifikan terhadap keinginan untuk menetap (intention to stay). Akan tetapi, variabel karakteristik pekerjaan yang paling memiliki peranan paling besar terhadap keinginan karyawan untuk menetap di PT. XY.

Saran bagi penelitian selanjutnya adalah penggunaan model penelitian yang lebih kompleks. Hal ini dikarenkan dalam penelitian ini model penelitian yang digunakan bersifat umum (generik). Selain itu, peranan aspek keadilan organisasi, karakteristik pekerjaan dan pemberdayaan psikologis terhadap keinginan untuk menetap karyawan milenial PT. XY sebesar 32\%, artinya bahwa masih ada faktor lainnya yang memiliki peran lebih besar terhadap keinginan untuk menetap karyawan dan penelitian selanjutnya dapat mencari faktor lain tersebut. Terakhir, penelitian kali ini tidak dapat digeneralisir. Butuh penelitian lebih lanjut terhdap bidang usaha lainnya untuk membuktikan bahwa keadilan organisasi, karakteristik pekerjaan dan pemberdayaan psikologis memiliki peran yang signifikan terhadap keinginan menetap karyawan milenial.

Saran bagi partisipan yakni pihak manajemen PT. XY adalah melakukan sosialisai agar para pemimpin di PT. XY dapat lebih cepat dan tepat memberikan umpan balik kepada karyawan. Tak hanya itu perlunya re-design pekerjaan yang lebih menuntut karyawan menggunakan keterampilan yang bervariasi sehingga mereka merasa pekerjaan yang dilakukan dapat berguna atau berdampak bagi orang lain. 


\section{Ucapan Terima Kasih (Acknowledgement)}

Peneliti mengucapkan terima kasih kepada pihak manajemen PT. XY yang telah memberikan izin untuk mengambil data terkait penelitian ini. Selain itu, peneliti juga menghaturkan rasa terima kasih kepada seluruh partisipan yakni karyawan milenial yang sudah bersedia berpartisipasi dalam penelitian kali ini.

\section{REFERENSI}

Ali, F. (2015). The effect of job characteristics on manager's intent to leave the organization: The Mediating role of the four dimensions of organizational commitment. International Journal of Business and Management, 10(6), 239-250.

Bayarçelik, E. B., \& Findikli, M. A. (2016). The mediating effect of job satisfaction on the relation between organizational justice perception and intention to leave. Procedia-Social and Behavioral Science, 235, 403-411.doi: 10.1016/j.sbspro.2016.11.050

Brandis, S., Fisher, R., McPhail, R., Rice.J., Eljiz, K., Fitzgerald, A., Gapp, R., \& Marshall, A. (2016). Hospital employees' perceptions of fairness and job satisfaction at a time of transformational change. Australian Health Review, 40, 292-298. doi: dx.doi.org/10.1071/AH15031.

Deloitte.(2016). Deloitte Millennial survey-winning over the next generation of leaders. Retrieved from www.deloitte.com/millennialsurvey

Dewettinck, K., \& Ameijde, M. (2011). Linking leadership empowerment behavior to employee attitudes and behavioural intentions: Testing the mediating role of psychological empowerment. Personnel Review, 40(3), 284-305.doi: 10.1108/0048348111111862

Djastuti, I. (2011). Pengaruh karakteristik pekerjaan terhadap komitmen organisasi karyawan tingkat managerial perusahaan jasa konstruksi di jawa tengah. Jurnal Bisnis dan Akutansi, 13(1), 1-19.

Gallup. (2016). How millennials wants to work and live. Diunduh dari http:// www.gallup.com/ reports/ 189830/ millennials-work-live.aspx? utm_source $=$ gbj \& utm - medium $=$ copy $\&$ utm_campaign $=20160809$-gbj

George, J., \& Wallio, S. (2017). Organizational justice and millenial turnover in public accounting. Employee Relations, 39(1),112-126. doi: dx.doi.org/10.1108/ER-11-2015-0208

Johnson, J.S. (2007). Organizational justice, moral ideology, and moral evaluation as antecedents of moral intent (Doctoral disertation). Virginia Polytechnic Institute and State University.

Larkin, I.M., Dias, L.B., \& Vega, A.L.(2016). Job satisfaction, organizational commitment and turnover intention of online teachers in the k-12 setting. Online Learning, 20 (3), 27-51.

Lunardi, A. (2012). Pengaruh karakteristik kerja dan kepuasan kerja terhadap keterikatan kerja pengemudi di mitra pt.xy (Tesis). Universitas Tarumanagara: Jakarta.

Najafi, S., Noruzy, A., Azar, H.K., Shirkouhi, S.N., \& Dalvand, M.R.(2011). Investigating the relationship between organizational justice, psychological empowerment, job satisfaction,organizational commitment and organizational citizenship behavior : An empirical model. African Journal of Business Management, 5(13), 5241-5248. doi: 10.5897/AJBM10.1505

Nojani, M.I., Arjamndnia, A.A., Afrooz, G.A., \& Rajabi, M. (2012). The study on relationship between organizational justice and job satisfaction in teachers working in general, special and gifted education systems. Procedia -Social and Behavioral Science, 46, 2900-2905. doi: 10.1016/j.sbspro.2012.05.586 
Ouyang, Y.Q, Zhou, W.B., \& Qu, H. (2015). The impact of psychological empowerment and organizational commitment on Chinese nurses' job satisfaction. Contemporary Nurse. doi : dx.doi.org/10.1080/10376178.2015.1010253

Ozturk, A.B., Hancer,M., \& Im, J.Y. (2014). Job characteristics, job satisfaction and organizational commitment for hotel workers in Turkey. Journal of Hospitality Marketing \& Management, 294313. doi: 10.1080/19368623.2013.796866

Putri, A.D. (2017). Peran kualitas kehidupan kerja, pemberdayaan psikologis dan persepsi peluang kerja terhadap intensi pindah kerja (Tesis). Universitas Tarumanagara, Jakarta.

Pramita, E. (2017). Karakteristik karyawan generasi millenial dalam bekerja. Diunduh dari : http://majalahkartini.co.id/keluarga-karier/dunia-kerja/karakteristik-karyawan-generasimillenial-dalam-bekerja/

Shobirin, M., Minarsih, M.M., Fathoni, A. (2016). Analisis pengaruh kepemimpinan, komitmen organisasi, dan kepuasan kerja terhadap keinginan pindah kerja karyawan PT. Bank BTPN Mitra Usaha Rakyat area Semarang 1. Journal of Management, 2(2).

Sidharta, N., Margaretha, M. (2011). Dampak komitmen organisasi dan kepuasan kerja terhadap turnover intention: Studi empiris pada karyawan bagian operator di salah satu perusahaan Garment di Cimahi. Jurnal Manajemen, 10(2), 129 -142.

Spreitzer, G.M. (1995). Psychological empowerment in the workplace: dimension, measurement and validation. Academy of Management Journal, 38(5), 1442-1465.

Stassen, M.A., \& Ursel, N.D. (2009). Perceived organizational support, career satisfaction, and the retention of older workers. Journal of Occupational and Organizational Psychology, 82, 201220. doi: 10.1348/096317908X288838 